Readers are invited to submit letters for publication in this department. Submit letters online at http://joem.edmgr.com. Choose "Submit New Manuscript." A signed copyright assignment and financial disclosure form must be submitted with the letter. Form available at www.joem.org under Author and Reviewer information.

\section{Response to Letter to the Editor On the Mortality of Talc Miners and Millers From Val Chisone, Northern Italy}

\section{Reply:}

T he issue of the alleged contamination of talc from Val Chisone was extensively discussed in previous reports on the mortality of the cohort of talc miners and millers, ${ }^{1,2}$ and we did not address it at length in our new report, ${ }^{3}$ but the letter by Dr. Finkelstein raises again the hypothesis of contamination and requires a detailed response.

This hypothesis was raised in the past, mainly in the framework of litigation, without any published supporting data. Conversely, there is strong evidence that talc from Val Chisone is not contaminated by tremolite or other asbestos fibers. In a 1972 study, Lighfoot et $\mathrm{al}^{4}$ reported the results of the analysis of 57 samples from Val Chisone mine: in none of the talc samples, there was asbestos contamination. Tremolite and anthophyllite were present (sometimes in nonfibrous form) in a few specimens of the foot wall rocks. In particular, they analyzed nine samples of "old powders and shipments" (final products), which were all free of any fibrous contamination. These results were quoted in the first mortality study of the cohort of miners and millers, published in $1976 .{ }^{1}$ Supporting evidence was provided by a 1982 paper by other authors, ${ }^{5}$ in which results based on $\mathrm{X}$-ray diffraction and infrared reflection spectrometry showed no contamination by tremolite or other amphiboles. Furthermore, in a 1983 report, Pooley ${ }^{6}$ stated:
"White Pinerolo Talc - this powder was found to be the most pure talc observed. The only impurity was a very small quantity of the mineral chlorite. Electron microscopic examination of this powder did not reveal any fibrous mineral particulates. Grey Pinerolo Talc - the major mineral observed in this sample by X-ray diffraction was chlorite and talc was present at the $25-30 \%$ level; a small quantity of dolomite was also observed. Again electrom microscope examination of this sample did not reveal any fibrous mineral particulate."

The results of the first analysis by Lighfoot et $\mathrm{al}^{4}$ were quoted by Gordon et al, ${ }^{7}$ who mistakenly interpreted the presence of tremolite in some samples of the footwall rocks as evidence of contamination of the talc ore and the final product used to produce the cosmetic talc. It is noteworthy the fact that this last paper includes a coauthor named Fitzgerald, that is, the name of the person quoted by Dr. Finkelestein as a source of unpublished analysis of one sample of talc from Val Chisone. The paper by Gordon et $\mathrm{al}^{7}$ was criticized by Lee and Van Orden ${ }^{8}$ : these authors identified several methodological errors in the study by Gordon et $\mathrm{al}^{7}$ and a severe amount of misinterpretation of literature. We think that the issue of contamination of Val Chisone talc by tremolite or other asbestos fibers should be finally put to rest.

The data of our cohort confirm, with a follow-up extended to a maximum of 66 years, ${ }^{3}$ our previous observation that occupational exposure to Val Chisone talc is not associated with an increased risk of mesothelioma. $^{1,2}$ In the new study, we observed no deaths from mesothelioma, and could exclude a two-fold excess risk. Dr. Finkelstein's calculation of the statistical power of our study is purely speculative, given the lack of support to the hypothesis of $4 \%$ asbestos exposure (or any other value different from zero) compared with Québec miners.
Enrico Pira, MD

Maurizio Coggiola, MD Catalina Ciocan, MD

Canzio Romano, MD

Department of Public Health and Pediatric Sciences

University of Turin Turin, Italy

Carlo La Vecchia, MD

Claudio Pelucchi, PhD

Department of Clinical Sciences and Community Health

University of Milan

Milan, Italy

Paolo Boffetta, MD, MPH

Tisch Cancer Institute

Icahn School of Medicine at Mount Sinai New York, New York

\section{REFERENCES}

1. Rubino GF, Scansetti G, Piolatto PG, Romano C. Mortality study of talc miners and millers. J Occup Med. 1976;18:186-193.

2. Coggiola M, Bosio D, Pira E, et al. An update of a mortality study of talc miners and millers in Italy. Am J Ind Med. 2003;44:63-69.

3. Pira E, Coggiola M, Ciocan C, et al. Mortality of talc miners and millers from Val Chisone, Northern Italy: an updated cohort study. J Occupat Environ Med. 2017;59:659-664.

4. Lighfoot J, Kingston GA, Pooley FD. An Examination of Italian Mine Samples and Relevant Powders. Cardiff, UK: Department of Mineral Exploitation, University College Cardiff; 1972.

5. Verdel U, Sperduto B, Perrone G B, Laurini C. [Talc varieties in the main Mediterranean deposits (France, Italy and Spain), and contaminating minerals]. Riv Inf Mal Prof. 1983;6:725-736 (in Italian).

6. Pooley FD. Report of the Examination of Talc Specimen. Cardiff, UK: Department of Mineral Exploitation, University College Cardiff; 1983.

7. Gordon R, Fitzgerald S, Millette J. Asbestos in commercial cosmetic talcum powder as a cause of mesothelioma in women. Int J Occup Environ Health. 2014;20:318-332.

8. Lee RJ, Van Orden D. Asbestos in commercial cosmetic talcum powder as a cause of mesothelioma in women. Int J Occup Environ Health. 2015;21:337-341.

The work was conducted using funds of the participating institutions.

EP, CC, CR, CLV, CP, and PB declare no conflicts. $\mathrm{MC}$ is an occupational physician for Imerys Talc Italy $\mathrm{SpA}$.

Address correspondence to: Paolo Boffetta, MD, MPH, Tisch Cancer Institute, Icahn School of Medicine at Mount Sinai, One Gustave L. Levy Place, Box 1130, New York, NY 10029 (paolo.boffetta@mssm.edu).

Copyright (C) 2017 American College of Occupational and Environmental Medicine

DOI: 10.1097/JOM.0000000000001138 